\title{
Imaging exams of bone lesions in patients with diffuse cutaneous leishmaniasis (DCL)
}

\author{
Af Ali U.M.L. Costa ${ }^{a}$, Ana C.R. Saldanha ${ }^{a}$, Bruno M.C. Leite ${ }^{b}$, Bruno Ramos $^{b}$, \\ Ibraim A. Junior $^{\mathrm{b}}$, Almério L.L. Noronha ${ }^{\mathrm{d}}$, André Báfica $^{\mathrm{d}}$, A. Barral $^{\mathrm{d}}$, \\ Carlos E.P. Corbett ${ }^{\mathrm{c}}$, Jackson M.L. Costa ${ }^{\mathrm{d}}$,* \\ ${ }^{a}$ Nucleus of Tropical Pathology and Social Medicine, Department of Pathology, Federal University of Maranhão, \\ São Luis, MA, Brazil \\ ${ }^{\mathrm{b}}$ Nuclear Medicine Service (Nuclear Maranhão Clinic), São Luis, MA, Brazil \\ ${ }^{c}$ Laboratory of Immunopathology (LIM-50), Department of Pathology, University of São Paulo, \\ São Paulo, SP, Brazil \\ d Gonçalo Moniz Research Center, FIOCRUZ/BA, Salvador, BA, Brazil
}

Received 17 December 2004

\begin{abstract}
We studied bone lesion alterations in three patients with diffuse cutaneous leishmaniasis (DCL) by imaging exams (radiography and scintigraphy) and histopathology. Two patients had bone lesions of distal extremities of hands and feet, and one infiltrating plaques in the skin. The study was conducted at three specialized centers (Presidente Dutra Hospital/Nucleus of Tropical Pathology, UFMA-MA; Gonçalo Moniz Research Center-FIOCRUZ-BA; Laboratory of Pathology of Infectious Diseases (LIM-50), University of São Paulo, SP). Three-phase bone scintigraphy demonstrated high sensitivity and specificity for bone lesions, showing increased uptake of the radiopharmaceutical at sites of active lesions. In contrast, radiography demonstrated lytic lesions, cortical destruction and local osteopenia of the bone extremeties in two patients. Histopathological analysis showed sequestration with presence of amastigote forms of Leishmania (osteomyelitis), mononuclear cells and macrophages containing amastigote forms of Leishmania in one patient. These preliminary data indicate that imaging exams (radiography and scintigraphy) are important in the evaluation of bone lesions in diffuse cutaneous leishmaniasis and should be included in the routine histopathological diagnosis of the disease and follow-up of bone lesions.
\end{abstract}

(c) 2005 Elsevier B.V. All rights reserved.

Keywords: Diffuse cutaneous leishmaniasis; Bone alterations; Imaging exams; Scintigraphy

\footnotetext{
* Corresponding author. Present address: Laboratório de Imunoparasitologia (LIP) do Centro de Pesquisas Gonçalo Moniz-FIOCRUZ/BA, Rua Valdemar Falcão, 121 Brotas/Salvador-Bahia, CEP 40295-001, Brazil. Tel.: +55 7135687 82x261; fax: +55 $713568782 x 261$.

E-mail address: jcosta@cpqgm.fiocruz.br (J.M.L. Costa).
} 


\section{Introduction}

Diffuse cutaneous leishmaniasis (DCL) is a rare variant of cutaneous leishmaniasis (CL) and differs from the other forms of the disease by the presence of lesion polymorphism characterized by nodules, infiltrated plaques, tubercles and exulcerations that affect different segments of the body. The intradermal skin test (Montenegro reaction) is negative and the therapeutic response is weak, a fact leading to constant recurrences during the course of the disease (Silva, 1945; Convit and Lapenta, 1946; Barrientos, 1948; Rabello, 1978; Costa et al., 1992). In Brazil, DCL is concentrated in the north and northeast regions, with the highest number of cases being reported from the State of Maranhão (Porto and Portugal, 1960; Costa et al., 1991, 1992, 1998; Saldanha et al., 1992).

According to Guimarães and Silva (1957), CL only affects cartilage, while other authors reported the involvement of bone, although the latter can be considered a rare event (Costa, 1953). Silva (1945) reported the case of a patient with CL who presented keloid, sometimes ulcerated, lesions in the upper and lower limbs accompanied by bone deformities, a finding that led the author to propose a new clinical form of the disease (keloid form). The clinical and radiological aspects of individuals with mutilations of the fingers and toes were described in detail only years later, with the signs and symptoms of the disease being compatible with chronic osteomyelitis (Arias, 1930; Arias and Rosa, 1931; Costa, 1953; Saldanha et al., 1995).

Some theories have tried to explain this involvement: according to Barros et al. (1952), bone destruction is the result of inflammatory processes or of specific mucosal lesions that occur adjacent to bone tissue. Guimarães and Silva (1957), defended a hematogenic cause and other investigators believe that bone alterations occur due to contiguity with the cutaneous lesions (Medina and Lizardo, 1960; Saldanha et al., 1995).

In bone tissue, metabolic alterations frequently precede anatomical changes and the use of imaging methods with a high sensitivity and specificity for bone infections might permit the early diagnosis of these alterations (Schauwecker, 1992). We describe here the use of these exams in three patients with DCL caused by Leishmania (L.) amazonensis. The aim of the present preliminary investigation was to help in the diagno- sis of bone lesions that sometimes accompany the disease.

\section{Material and methods}

The study was carried out during a period of 12 months (December 1999 to January 2000) at three specialized services (Presidente Dutra University Hospital-HUPD/Nucleus of Tropical Pathology of the Federal University of Maranhão-UFMA, Gonçalo Moniz Research Center/CPQGM-FIOCRUZBahia and Laboratory of Immunopathology (LIM-50), University of São Paulo-USP).

Three patients previously diagnosed with DCL caused by L. amazonensis (Costa et al., 1998) were selected, two with disseminated nodule vegetating and infiltrating lesions associated with secondary infection and one with infiltrating plaques. The patients were hospitalized at HUPD for laboratory examination, including imaging exams, biopsies of the cutaneous and bone lesions and specialized clinical treatment. Informed consent was obtained from the patients and the study was approved by the Ethics Committee of HUPD-UFMA.

Blood flow, balance $(5 \mathrm{~min})$ and bone $(3 \mathrm{~h})$ scans were obtained by three-phase bone scintigraphy after injection of 99mTc-MDP (diphosphonate labeled with 99m-technetium) using a GE gamma camera (model STARCAM 3200i) and analyzed by a specialized team from the area of nuclear medicine who were unaware of the clinical and radiographic findings.

In the sequence, patients were then submitted to radiographic examination of the extremities in two planes (anteroposterior and profile), mainly hands and feet, with the results always being correlated with the deformities observed upon clinical examination.

In addition, biopsies were taken from cutaneous lesions, fixed in $10 \%$ formalin and stained with hematoxylin-eosin for histopathological examination. In a next step, bone biopsies were obtained from the area adjacent to the skin lesions with bone biopsy needles based on the previously analyzed radiographies and scintigraphy, thus preventing contamination of the samples as proposed by Jesus-Garcia (1987a,b) and Ghelman (1998). When reaching the bone, fragments were collected from the affected area, and the material was stored in sterilized flasks containing $10 \%$ 
formalin and sent to the pathology service of HUPD and CPQGM for histopathological analysis by light microscopy.

\section{Results}

In one patient (J.S.C.), radiographic examination revealed the presence of lytic and degenerative lesions in the distal phalanges of the fingers and toes. Scintigraphy showed increased uptake of the radiopharmaceutical in the distal phalanges of the first, third, fourth and fifth finger of the left hand.

The other two patients (R.F.O. and M.C.M.A.) presented diffuse osteopenia in the hands and feet upon radiography, with the absence of a periosteal reaction. Patient R.F.O. showed tapering of the proximal third of the distal phalanges and partial resorption of the phalanges. Scintigraphy revealed increased uptake of the radiopharmaceutical in bone tissue in both patients. Figs. 1-7 show the clinical (see Figs. 1, 4 and 5), radiological (see Figs. 2 and 6) and scintigraphic (see Figs. 3 and 7) aspects of two patients.

Bone tissue consisted of bone fragments containing histopathologically normal compact cortical bone and fragments of fibrous connective tissue. The presence of mononuclear inflammatory cells and macrophage containing amastigote forms of Leishmania and bone sequestration with amastigote of Leish-

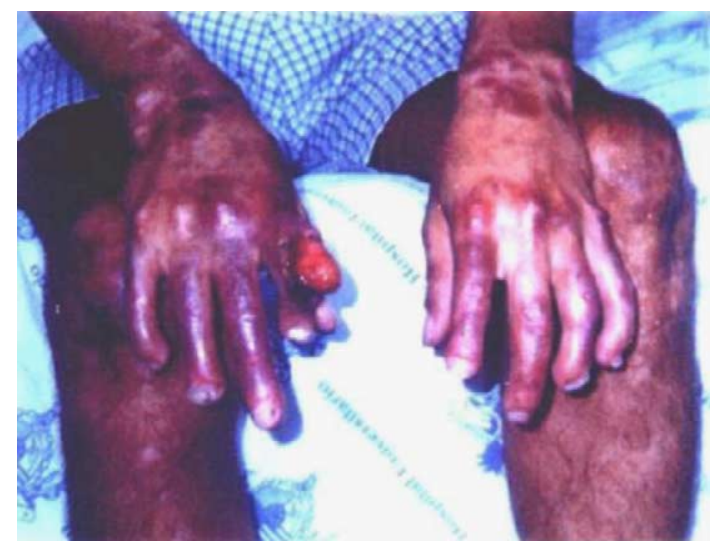

Fig. 1. Patient J.S.C.- - lesions in infiltrated plaques, with some areas showing hyperchromia on the fingers of right and left hands. First and second fingers of right hand showing an extensive exulcerated lesion with tumoral aspect and apparent shortening of the fingers.

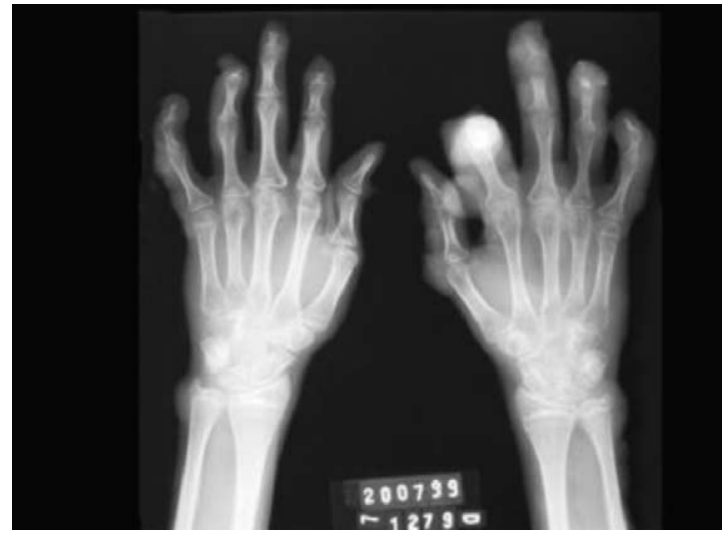

Fig. 2. Radiological aspects-symmetric, lytic and degenerative lesions in the distal phalanges of the fingers. Absence of a periosteal reaction and marked osteopenia with tapering of the cortical bone and reduced interdigital spaces, shortening of these rays.

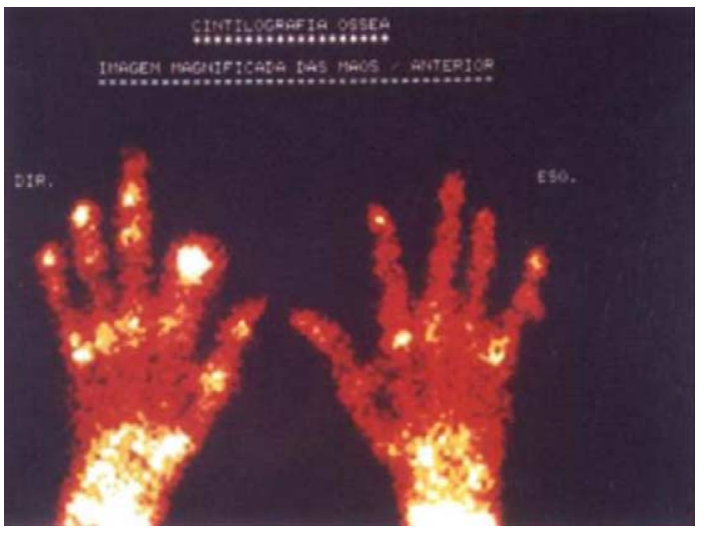

Fig. 3. Bone scintigraphy-note the abnormal increased uptake hyperfixation in the metacarpal-phalangeal joint of the fifth ray and the distal phalanges of the first, third, fourth and fifth finger of the right hand and increased uptake in the distal phalanges of the second and fifth finger of the left hand.

mania (osteomyelitis) were noted in one patient. The clinical, radiological, scintigraphic and histopathological data are summarized in Table 1.

\section{Discussion}

The bone alterations observed in DCL are characterized by shortening of the phalanges, especially the distal phalanges of the hands due to bone destruction 


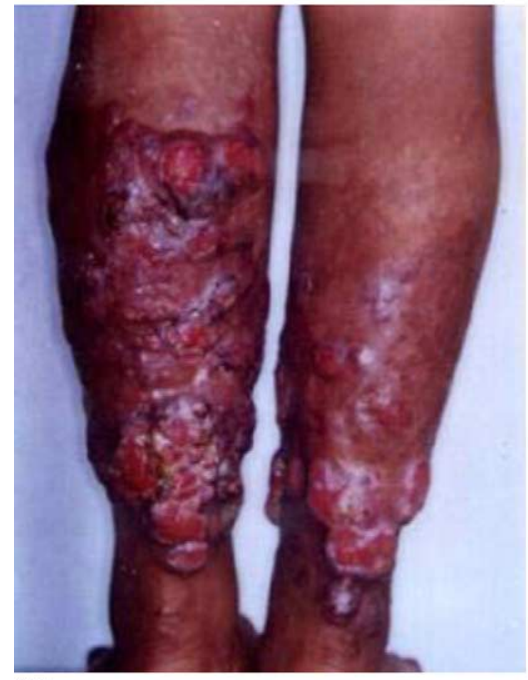

(4)

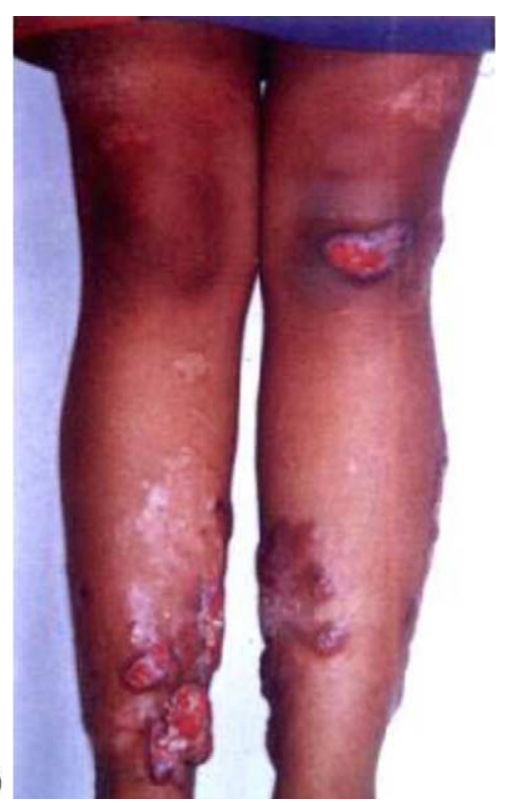

(5)

Figs. 4 and 5. Patient M.C.M.A. - lower limbs, right and left legs; anterior view - extensive exulcerated lesions, some with a vegetant aspect affecting the middle third and lower legs. Left side: extensive infiltrating nodulous plaque associated with hyperchromia. Posterior view: extensive infiltrating plaques with exulcerated lesions, some showing an ulcer-vegetating aspect and surrounding hypercromia, while few lesions presented a tubercle-like aspect.

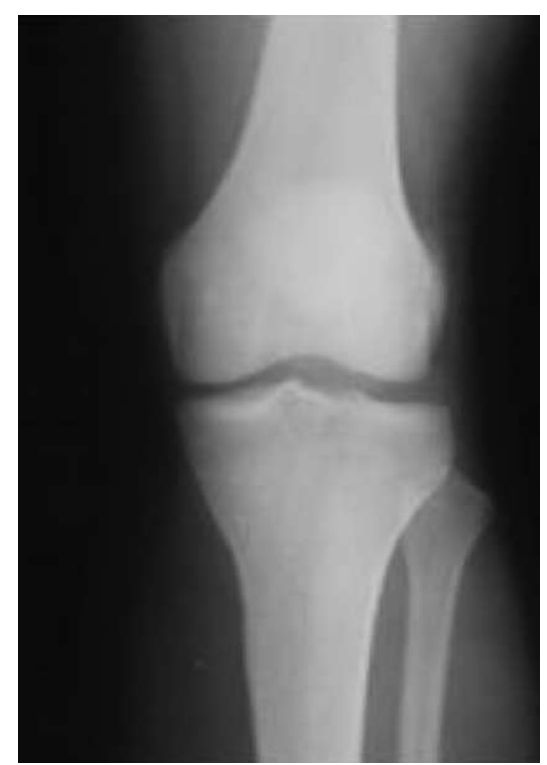

Fig. 6. Left knee - radiological aspects - absence of a periosteal reaction, lytic lesion and cortical destruction.

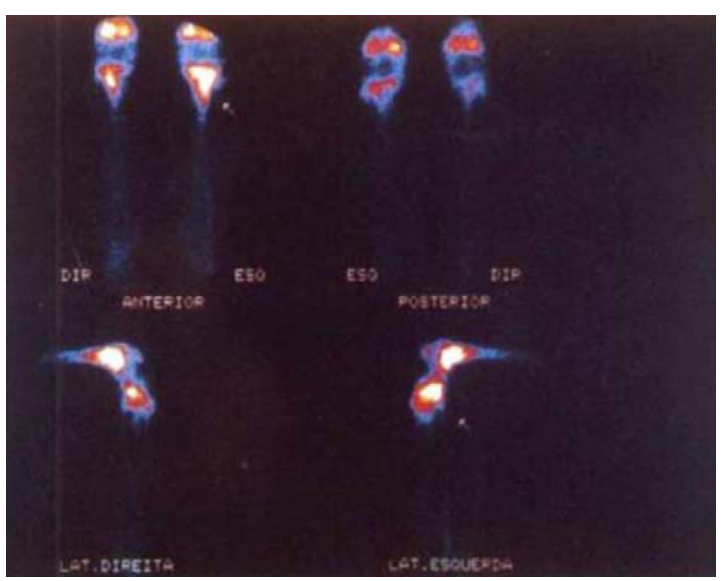

Fig. 7. Scintigraphy. (A) Late increased uptake of the radiopharmaceutical in the proximal third on both sides. Presence of scintigraphic signs of an infectious inflammatory process in the soft parts of the distal third of the right leg. (B) Abnormal increased uptake in the proximal third of the left tibia, in addition to scintigraphic signs of an infectious inflammatory process in the soft parts of the distal third of the right leg. 
Table 1

Clinical, radiological, scintigraphic and histopathological aspects of the three patients with diffuse cutaneous leishmaniasis (DCL) studied at HUPD-UFMA

\begin{tabular}{|c|c|c|c|c|}
\hline \multirow[t]{2}{*}{ Patient } & \multirow[t]{2}{*}{ Clinical characteristics } & \multicolumn{3}{|l|}{ Exam } \\
\hline & & Radiological aspects & Scintigraphic aspects & Histopathological aspects \\
\hline J.S.C. & $\begin{array}{l}\text { A 18-year-old male from } \\
\text { Eugênio de Barros-MA. } \\
\text { Affected by DCL for } 8 \\
\text { years. Clinical data: } \\
\text { nodule vegetating, } \\
\text { infiltrating, ulcerating } \\
\text { lesions with secondary } \\
\text { infection of the nose, ears, } \\
\text { hands and feet. } \\
\text { Shortening and } \\
\text { deformation of the fingers } \\
\text { and toes-limited } \\
\text { articular function }\end{array}$ & $\begin{array}{l}\text { Symmetric, lytic and } \\
\text { degenerative lesions in } \\
\text { the distal phalanges of the } \\
\text { fingers and toes. Absence } \\
\text { of a periosteal reaction } \\
\text { and marked osteopenia, } \\
\text { with tapering of the } \\
\text { cortical bone and reduced } \\
\text { interdigital spaces. } \\
\text { Shortening of these rays }\end{array}$ & $\begin{array}{l}\text { Increased uptake of the } \\
\text { radiopharmaceutical in } \\
\text { the distal phalanges of the } \\
\text { first, third, fourth and fifth } \\
\text { finger of the right hand, } \\
\text { and second and fifth } \\
\text { finger of the left hand. } \\
\text { Increased uptake in the } \\
\text { middle phalanx of the } \\
\text { third, fourth and fifth } \\
\text { metacarpal and left } \\
\text { phalangeal joints and } \\
\text { bones of the left foot }\end{array}$ & $\begin{array}{l}\text { Cutaneous lesions: atrophic } \\
\text { epidermis. Dense macrophage } \\
\text { infiltrate containing amastigote } \\
\text { forms of Leishmania within } \\
\text { parasitophorous vacuoles. } \\
\text { Evidence of extensive } \\
\text { degradation of the connective } \\
\text { collagen matrix. Bone lesions: } \\
\text { compact cortical bone without } \\
\text { histological alterations, bone } \\
\text { sequestration with amastigotes of } \\
\text { Leishmania (osteomyelitis } \\
\text { caused by Leishmania) and } \\
\text { fragments of normal fibrous } \\
\text { connective tissue (normal } \\
\text { periosteum), with the presence of } \\
\text { mononuclear inflammatory cells } \\
\text { and macrophages containing } \\
\text { Leishmania. } \\
\text { Immunohistochemistry-heavy } \\
\text { positive for Leishmania }\end{array}$ \\
\hline R.F.O. & $\begin{array}{l}\text { A 26-year-old male from } \\
\text { Coelho Neto-MA. } \\
\text { Affected by DCL for } 20 \\
\text { years. Clinical data: } \\
\text { Nodule infiltrating lesions } \\
\text { in the nose, ears, fingers } \\
\text { and toes. Ulcerations with } \\
\text { secondary infection of the } \\
\text { left leg. Deformities of } \\
\text { the fingers with } \\
\text { shortening and limited } \\
\text { articular function }\end{array}$ & $\begin{array}{l}\text { Diffuse osteopenia of the } \\
\text { hands and feet. Absence } \\
\text { of a periosteal reaction. } \\
\text { Tapering of the proximal } \\
\text { third of the distal } \\
\text { phalanges of the fingers } \\
\text { and toes. Partial } \\
\text { resorption of the distal } \\
\text { phalanges of the fingers } \\
\text { and toes and reduced } \\
\text { interdigital articular } \\
\text { space, leading to } \\
\text { shortening of these rays }\end{array}$ & $\begin{array}{l}\text { Increased uptake of the } \\
\text { radiopharmaceutical in } \\
\text { bone tissue }\end{array}$ & $\begin{array}{l}\text { Cutaneous lesions: atrophic } \\
\text { epidermis. Macrophage infiltrate } \\
\text { containing amastigote forms of } \\
\text { Leishmania. Scarcity of } \\
\text { lymphocytes and plasma cells. } \\
\text { Evidence of connective matrix } \\
\text { degradation and discrete } \\
\text { pericellular and perivascular } \\
\text { fibrogenesis at inflammatory foci. } \\
\text { Bone lesions: compact cortical } \\
\text { bone without histological } \\
\text { alterations and fragments of } \\
\text { normal fibrous connective tissue }\end{array}$ \\
\hline M.C.M.A. & $\begin{array}{l}\text { A 19-year-old female } \\
\text { from Urbano Santos-MA. } \\
\text { Clinical data: Affected by } \\
\text { DCL for } 12 \text { years. Nodule } \\
\text { vegetating lesions in the } \\
\text { nose and ears. Legs with } \\
\text { ulcerations and secondary } \\
\text { infection. Absence of } \\
\text { deformities of the hands } \\
\text { and feet }\end{array}$ & $\begin{array}{l}\text { Diffuse osteopenia of the } \\
\text { hands and feet. Absence } \\
\text { of a periosteal reaction, } \\
\text { lytic lesions and/or } \\
\text { cortical destruction. Bone } \\
\text { segments without } \\
\text { deformities }\end{array}$ & $\begin{array}{l}\text { Increased uptake of the } \\
\text { pharmaceutical in the } \\
\text { proximal third of the left } \\
\text { tibia }\end{array}$ & $\begin{array}{l}\text { Cutaneous lesions: dermis } \\
\text { showing an intense macrophage } \\
\text { infiltrate, with large } \\
\text { parasitophorous vacuoles } \\
\text { containing amastigote forms of } \\
\text { Leishmania. Small number of } \\
\text { lymphocytes and plasma cells, } \\
\text { some areas with various } \\
\text { eosinophils. Inflammatory foci } \\
\text { showing discrete pericellular and } \\
\text { perivascular fibrogenesis and } \\
\text { extensive degradation of the } \\
\text { collagen matrix. Bone lesions: } \\
\text { compact cortical bone without } \\
\text { histological alterations, } \\
\text { fragments of normal fibrous } \\
\text { connective tissue }\end{array}$ \\
\hline
\end{tabular}


and to a reduction in articular space, leading to deformities of skeletal extremities, limiting articular movement and impairing habitual daily life activities (Silva, 1958; Saldanha et al., 1995).

Usually, no return to the normal bone aspect is observed. Almeida (apud, Guimarães and Silva, 1957), carrying out control radiographic exams, demonstrated complete regression of all lesions, with the affected bone recovering its normal shape and structure. The author concluded that irrespective of the mechanism the parasite causes characteristic lesions in the bone tissue, which permit their distinction from other diseases such as bacterial osteomyelitis, syphilis or bone tuberculosis that are characterized by signs and symptoms of condensing chronic osteitis (Arias, 1930; Costa, 1953).

In the present study, such lesions were not detected by this imaging method in only one patient, although the patient was in the active phase of the disease. These deformities are irreversible and evolutive, impairing the execution of basic daily life tasks.

Radiography represents a low cost method, being important for the localization, determination of the extent and presence or absence of a periosteal reaction and the type of lesion destruction (Jesus-Garcia, 1996; Schajowicz, 2000). In the present study, this method permitted the determination of the symmetric character of the lesions on hands and feet, which were similar in the two patients.

Kochs (1969) described a case of leishmaniasis ulcers affecting the medial malleolus of the ankle detected by radiography in a patient with mucocutaneous leishmaniasis. Barros et al. (1952) characterized the bone alterations found in diseases such as cutaneous leishmaniasis, establishing a radiological picture that could help with the definitive or probable diagnosis; however, various bone lesions show the classic appearance of some specific type of pathology, while many others are nonspecific (Leanne et al., 1998).

Braga et al. (1992) and Braga (2002) reported the importance of the study of tropical diseases by scintigraphic methods. No studies on bone involvement in DCL determined by bone scintigraphy are available in the literature. However, this method seems to be important for the localization and definition of the extent of the lesion and for the monitoring of disease activity. Bone scans were found to be efficient in the present study since they showed increased uptake in bone tissue, thus representing a method of choice for the deter- mination of infection of the musculoskeletal system or in patients with osteogenic activity (Schauwecker, 1992; Brown et al., 1993; Palestro and Torres, 1997). Although not presenting concordant bone involvement, one of the patients showed increased uptake of the drug probably due to some osteogenic activity or increased regional blood flow. In clinical practice, the use of imaging exams and the clinical understanding of the disease represent a dynamic approach to the analysis of bone lesions, since accumulation of a radiopharmaceutical is associated with specific histological alterations (McCarthy, 1997).

The histopathological results of the cutaneous lesions of the present patients showed scarcity of lymphocytes and plasma cells, and a dense infiltrate of macrophages which mainly contained the amastigote forms of Leishmania within parasitophorous vacuoles. In addition, an atrophic epidermis and extensive degradation of the connective collagen matrix were observed, findings similar to those reported by others (Barros et al., 1952; Guimarães and Silva, 1957; Bryceson, 1969).

In conclusion, radiographic and scintigraphic exams of bone lesions seem to play an important role in the identification, localization, follow-up and biopsy management of these lesions. The histopathological study of the lesions is essential for the elucidation of the pathogenesis of bone involvement in DCL.

We intend to continue this study with a larger number of cases and to establish an assessment protocol using imaging and histopathological methods.

\section{References}

Arias, A.C., 1930. Foco familiar de leishmaniasis tegumentar americana. 5 a Reun. Soc. Arg, Pat, Reg, del Norte 1, 590-594.

Arias, A.C, Rosa, A., 1931. Existem localizaciones óseas en leishmaniasis americana? $6^{\mathrm{a}}$ Reun. Soc. Arg. Pat. Reg. del Norte 2, 460.

Barrientos, P.L., 1948. Um caso típico de leishmaniose cutâneomucosa. Mem. Inst. Oswaldo Cruz 46, 415-418.

Barros, R.F., Lima, M.L.T., Correa, A.A., 1952. Alterações sinusais na leishmaniose nasal com estudo radiográfico e histopatológico. Rev. Clín. Fac. Med. Un. São Paulo 7, 145-150.

Braga, F.J.H.N., Abreu, C.M., Abreu, P.R., Camargo, E.E., Rivitti, M.C.M., Tedesco-Marchesi, L.C.M., Gambini, D.J., Barritaul, L., 1992. Contribution au début de l'étude de deux maladies infectieuses granulomateuses (La lépre et la leishmaniose cutanéé et muqueuse) par des méthodes scintigraphiques). Bull. Soc. Path. Ex. 85, 53-57. 
Braga, F.J.H.N., 2002. Nuclear medicine in tropical diseases. Brazil Arch. Biol. Technol. 45, 1-7.

Brown, M.L., Collier Jr., B.D., Fogelman, I., 1993. Bone Scintigraphy: Part 1. Onc. Inf. J. Nucl. Med. 34, 2236-2240.

Bryceson, A.D.M., 1969. Diffuse cutaneous leishmaniasis in Ethiopia I. The clinical and histological features of the disease. Trans. R. Soc. Trop. Hyg. 63, 708-737.

Costa, J.M.L., Saldanha, A.C.R., Silva, C.M.P., Serra-Neto, A., Galvão, C.E.S., Godinho, A.M.R., Silva, A.C., Mendes, W.S., Silva, A.C.M., 1991. Estágio atual da leishmaniose cutânea difusa (LCD) no Estado do Maranhão I. Relato Preliminar. Rev. Soc. Bras. Med. Trop. 24, 59-60.

Costa, J.M.L., Saldanha, A.C.R., Melo e Silva, A.C., Serra-Neto, A., Galvão, C.E.S., Pedroso e Silva, C.M., Silva, A.R., 1992. Estado atual da leishmaniose cutânea difusa (LCD) no Estado do Maranhão II. Aspectos epidemiológicos, clínico-evolutivos. Rev. Soc. Bras. Med. Trop. 25, 115-123.

Costa, J.M.L., Cunha, A.K., Gama, M.E.A., Saldanha, A.C.R., 1998. Leishmaniose cutânea difusa: revisão. An. Bras. Derm. 73, 565-576.

Costa, O.G., 1953. Dactilitis Leishmaniótica. Arch. Arg. Derm. 3, 149-153.

Convit, J., Lapenta, P., 1946. Sobre un caso de leishmaniasis disseminada. Rev. Pat. Clin. 17, 153.

Ghelman, B., 1998. Biopsies of the musculoskeletal system: interventional procedures in musculoskeletal radiology I. Rad. Clin. North Am. 36, 567-580.

Guimarães, N., Silva, Y.P., 1957. Lesões ósseas da leishmaniose. An. Bras. Derm. Sifilog. 32, 5-7.

Jesus-Garcia, R., 1987a. Biópsia percutânea nas lesões neoplásicas do esqueleto. Rev. Bras. Cancer 32, 185.

Jesus-Garcia, R. 1996. Tumores Ósseos: Uma abordagem ortopédica ao estudo dos tumores ósseos. Universidade Federal de São Paulo.

Jesus- Garcia, R., 1987b. Estudo das técnicas de biópsia percutânea do esqueleto. Folha Méd. 95, 243.
Leanne, L., Seeger, M.D., Lawrence Yao, M.D., Jeffrey, J., Eckardt, M.D., 1998. Surface lesions of bone. Radiology 206, 1733.

Kochs, A.G., 1969. Sulla participazione ossea nella leishmaniase cutanea. Min. Derm. 99, 455-458.

McCarthy, E.F., 1997. Histopathologic correlates of a positive bone scan. Semin. Nucl. Med. XXVII, 309-320.

Medina, R., Lizardo, C., 1960. Leishmaniasis de la orega. Derm. Venez. 2, 54-57.

Palestro, C.J., Torres, M.A., 1997. Radionuclide Imaging in orthopedic infections. Semin. Nucl. Med. XXVII, 334-345.

Porto, M.A., Portugal, H., 1960. Leishmaniose tegumentar difusa. O Hospital 57, 11-23.

Rabello, F.E., 1978. Leishmaniose cutis difusa. An. Bras. Derm. 53, 157.

Saldanha, A.C.R., Mello e Silva, A.C., Galvão, C.E.S., Pedroso e Silva, C.M., Costa, J.M.L., 1992. Procedência de pacientes portadores de leishmaniose cutânea difusa (LCD) no Estado do Maranhão-Brasil. Rev. Soc. Bras. Med. Trop. 25, 271273.

Saldanha, A.C., Malheiros, T.S., Rodrigues, C.C.R., Balby, I.T.A., Costa, J.M.L., 1995. Alterações ósseas observadas na leishmaniose cutânea difusa (LCD) no estado do Maranhão. Rev. Soc. Bras. Med. Trop. 28, 55-56.

Schajowicz, F., 2000. Neoplasias ósseas e lesões Pseudotumorais: Patologia, Radiologia e Tratamento, $2^{\text {a }}$ Edição. Editora Revinter, RJ.

Schauwecker, D.S., 1992. The scintigraphic diagnosis of osteomyelitis. AJR 158, 9-18.

Silva, D., 1958. Leishmaniose tegumentar queloidiana, com lesões ósseas. An. Bras. Derm. Sifil. 33, 3-7.

Silva, F., 1945. Forma raríssima de leishmaniose tegumentar. Leishmaniose dérmica não ulcerada em nódulos e extensa placas infiltradas e hiperpigmentadas. Janeiro. Separata do volume de Reunião Anual de Dermato-sifilografos Brasileiros, Rio de Janeiro, pp. 97-103. 